\title{
Genetic heterogeneity in age classes of naturally regenerated old growth forest of Picea abies (L.) Karst.
}

\author{
By A. Wojnicka-PóŁtorak ${ }^{1)}$, W. WAChowiak ${ }^{2), 3)}$, W. Prus-GŁowacki ${ }^{1)}$, K. Celiński ${ }^{1)}$ and A. KorczYK ${ }^{4)}$
}

(Received $6^{\text {th }}$ September 2013)

\begin{abstract}
The Białowieża Primeval Forest is located northeastern Poland. It is one of Europe's most precious old growth forests in terms of abundance and richness of vegetation, retaining features of a primeval lowland forest which cannot be found anywhere else on the European continent. The aim of the study was to assess the genetic heterogeneity of the naturally regenerated Picea abies population using five chloroplast microsatellite markers. In total, 290 trees representing five age classes were studied. Clear patterns of genetic differentiation in relation to demographic substructuring were found within the population. The class of embryos exhibited the greatest genetic richness as evident from the highest number of alleles and haplotypes, the highest mean number of private alleles and haplotypes and the highest haplotype diversity. In the subsequent age classes, a significant decrease in the level of genetic variation was observed. Our data demonstrate that long-lived, highly outcrossing tree species growing in continuous stands can be genetically heterogeneous on a small geographic scale. The heterogeneity is related to age structure and it is likely due to the underlying mating system and selection processes.
\end{abstract}

Key words: cpSSR markers, age dynamics, genetic diversity, Białowieża Primeval Forest, Picea abies.

\section{Introduction}

The Białowieża Primeval Forest is located in northeastern Poland and belongs to Europe's most valuable pristine old growth forests in terms of abundance and richness of vegetation (KORCZYK, 2008). It has retained features of a primeval lowland forest which cannot be found anywhere else on the European continent. Due to its unique nature, the most valuable section of the Białowieża Forest was officially covered by a protection scheme in 1932 as the Białowieża National Park (Окоєów et al., 2009), the Poland's first national park and one of the first in Europe. The Białowieża Primeval

\footnotetext{
1) Department of Genetics, Institute of Experimental Biology, Faculty of Biology, Adam Mickiewicz University, Umultowska 89, 61-614 Poznań, Poland.

Corresponding author: telephone number: 48618295862. Mail: olawp@amu.edu.pl.

2) Institute of Dendrology Polish Academy of Sciences, Parkowa 5, Kórnik, Poland.

3) Institute of Environmental Biology, Faculty of Biology, Adam Mickiewicz University, Umultowska 89, 61-614 Poznań, Poland. E-Mail: witoldw@man.poznan.pl.

4) Bialystok University of Technology, Branch Faculty of Forest in Hajnówka, Piłsudskiego 8, 17-200 Hajnówka, Poland.

E-Mail: adolfkorczyk@gmail.com
}

Forest is one of only seven worldwide (and three in Europe) UNESCO transboundary biosphere reserves entered in the World Heritage List. Furthermore, the entire Polish section of the Białowieża Forest was designated as a Special Protection Area (SPA) and a Special Area of Conservation (SAC) within the framework of the Natura 2000 network of protected areas. A very characteristic feature of Białowieża's old-growth forests is their complex biodiversity structure with a variety of species including trees of extreme age classes. The Białowieża Primeval Forest is a mosaic of diverse habitats with a very high degree of biodiversity and a large proportion of ancient trees and natural population (primeval gene pool) (OKOŁów et al., 2009). It offers a unique opportunity for monitoring processes involved in natural regeneration of tree population in a completely developed forest ecosystem.

Old-growth forests are considered essential for maintaining biodiversity (MOSSELER et al., 2003). Genetic diversity of forest trees plays a major role in the stability and dynamics of forest ecosystems (SCHUELER et al., 2012). Knowledge of the genetic diversity and genetic structure is a prerequisite for managing and conserving populations of tree species (HAMRICK et al., 1992; Williams and HAMrick, 1996; GeBUREK, 1997). Genetic diversity is also crucial from the economic viewpoint because it determines the persistence of economically desirable features, represents a basis for selection towards improvement of certain tree properties and it can reduce negative impact of some biotic and abiotic factors (MATRAS, 2006). This is particularly important for Picea abies, one of the most ecologically and economically important forest tree species in Poland and Europe, managed intensively for more than 200 years. We still know very little about the dynamics of genetic variation due to demography in natural tree populations. Most of the studies on genetic diversity of tree populations refer to adult individuals or seedlings derived from sampled seeds (RoBERDs and CONKLE, 1984; Berg and Hamrick, 1995; Politov et al., 2006). However, there is still little understanding of the demographic genetic structures of populations within multiple age classes (KITAMURA et al., 1997). However, for long-lived trees, demographic genetic structures provide a chance to reveal the key factors influencing the genetic variation within populations (CHEN and SONG, 1997). It is important to take into account the dynamics of oldgrowth forests because they are related to natural regeneration processes. Analysis of age dynamics of the population genetic structure may be of key importance for better understanding of the mechanisms of mainte- 
nance of genetic diversity and evolution (KORSHIKOV and MUDRICK, 2006).

The goal of the present study was to assess intraspecific genetic diversity in age classes of the naturally regenerated Picea abies population from the Białowieża Primeval Forest using chloroplast microsatellite markers. Paternally inherited cp DNA SSR markers with high levels of variability have proved to be valuable for detecting genetic structure of populations in many conifer species (ECHT et al., 1998; VENDRAMIN et al., 1998; ZIEGENHAGEN et al., 1998). The uniparental inheritance, lack of heteroplasmy and recombination of organelle genome make them an attractive tool for within-species genetic studies (SoLTIS et al., 1992; ENNOS et al., 1999), pollen migration, population histories and levels of differentiation (Provan et al., 2001).

\section{Material and Methods}

\section{Plant material}

The research was conducted on naturally regenerated tree stand of Norway spruce (Picea abies) located in the Białowieża Primeval Forest in central-eastern Poland in Hajnówka forest division (section 631A). The only treatments applied recently in this compartment were removing of trees toppled over and infested by bark beetles (KoRCZYK, 1994).

Fresh needles from 232 trees representing four different age classes were collected. Those included 60 trees older than 100 years (old O), 55 trees between 100 and 11 years (middle-aged trees M), 59 trees of 10-4 years old (young trees Y) and 58 individuals up to 3 years old (seedlings $\mathrm{S}$ ). The age of each individual at the class $\mathrm{O}$ and $\mathrm{M}$ was estimated by their diameter at breast height and by counting their growth rings. The distance between sampled trees was between 10 to 100 meters. In addition, 58 embryos (E class) were obtained from the seeds of a few cones collected from 50 individuals of $\mathrm{M}$ and $\mathrm{O}$ age classes. Seeds were mixed together and formed a pooled sample which was germinated in a laboratory conditions.

\section{DNA extraction and chloroplast microsatellite screening}

DNA was extracted from needles (ca. $100 \mathrm{mg}$ of fresh material) and two-week-old seedlings with the standard CTAB (cetyltrimethylammonium bromide) protocol. Polymerase chain reaction (PCR) primers, previously derived from chloroplast genome sequence of Pinus thunbergii (VENDRAMIN et al., 1996), were used to analyze variation at five microsatellite loci: Pt63718, Pt26081, Pt15169, Pt30204 and Pt71936. The loci were selected because of their high polymorphism detected in previous studies (VENDRAMIN et al., 2000). The primers were multiplexed in PCR with the forward primer of each pair labeled with corresponding fluorescent dyes (Life Technologies). PCR-amplification was carried out in a total volume of $15 \mu \mathrm{l}$, containing about $10 \mathrm{ng}$ of template DNA, $2.5 \mathrm{mM} \mathrm{MgCl}_{2}, 100 \mu \mathrm{M}$ of each dNTP, $0.2 \mu \mathrm{M}$ of each primer and $0.25 \mathrm{U}$ Taq polymerase (Sigma-Aldrich) with the respective 1x PCR buffer. All multiplex PCR amplifications were performed in a PTC$200 \mathrm{MJ}$ Research thermocycler with the following cycle profile: initial denaturation for $5 \mathrm{~min}$ at $94^{\circ} \mathrm{C}$, followed by 30 cycles of $1 \mathrm{~min}$ denaturation at $94^{\circ} \mathrm{C}, 1 \mathrm{~min}$ annealing at $50^{\circ} \mathrm{C}, 1 \mathrm{~min}$ incubation at $72^{\circ} \mathrm{C}$ and $10 \mathrm{~min}$ final extension at $72^{\circ} \mathrm{C}$. PCR products were electrophoresed with an ABI Prism 310 DNA Sequencer (Life Technologies), and genotypes were scored with GeneScan and Genotyper software packages (Life Technologies).

\section{Chloroplast microsatellite data analysis}

The level of polymorphism of the whole population scale and within each age class was estimated using the number of alleles per locus (A), number of haplotypes (H) and haplotype diversity (NEI, 1978) with the use of GenAlex 6.5 (PeAKall and Smouse, 2012) and Statistica 10 software.

Table 1. - Number of alleles and haplotypes and haplotypic diversity $\mathrm{H}$ detected at five chloroplast microsatellites loci for particular age classes (number of private alleles and haplotypes in parenthesis).

\begin{tabular}{|c|c|c|c|c|c|c|c|c|}
\hline \multicolumn{9}{|c|}{ Number of alleles } \\
\hline I.ocus & SSR range & Toral & $O>100$ & M $11-100$ & Y 4-10 & $S 0-3$ & Fmbryos & Mean (s.d.) \\
\hline Total & & 26 & 17 & 18 & 18 & 18 & 22 & 19 \\
\hline Pt63718 & $93-99$ & $6 \quad(2)$ & $5 \quad(1)$ & 4 & 4 & $5(1)$ & 4 & $4.4(0.49)$ \\
\hline Pt2608l & $107-114$ & $6 \quad(2)$ & 3 & 4 (1) & 4 & 4 (1) & 4 & $3.8(0.4)$ \\
\hline$P 115169$ & $120-122$ & $3(1)$ & 1 & 2 & 2 & 1 & $3(1)$ & $1.8(0.748)$ \\
\hline Pt 30204 & $129-137$ & 6 & 4 & 3 & 5 & 4 & 6 & $4.4(1.020)$ \\
\hline $\mathrm{I}+71936$ & $141-145$ & $5 \quad(1)$ & 4 & 4 & 3 & 4 & $5 \quad(1)$ & $4.0(0.632)$ \\
\hline $\begin{array}{l}\text { Mean } \\
\text { (s.d.) }\end{array}$ & & $\begin{array}{l}5.2 \\
(1.166)\end{array}$ & $\begin{array}{l}3.4 \\
(1.356)\end{array}$ & $\begin{array}{l}3.4 \\
(0.800)\end{array}$ & $\begin{array}{l}3.6 \\
(1.020)\end{array}$ & $\begin{array}{l}3.6 \\
(1.356)\end{array}$ & $\begin{array}{l}4.4 \\
(1.020)\end{array}$ & $\begin{array}{l}3.7 \\
(1.111)\end{array}$ \\
\hline \multicolumn{2}{|c|}{ Number of haplotypes } & 54 & $20(5)$ & $20(5)$ & $22(5)$ & $22(6)$ & $26(8)$ & $22(2.19)$ \\
\hline \multicolumn{2}{|c|}{ Haplotypic diversity $\mathrm{H}$} & - & 0.378 & 0.393 & 0.531 & 0.354 & 0.518 & $0.435(0.005)$ \\
\hline
\end{tabular}


Table 2. - Results of the Analysis of Molecular Variance (AMOVA) for particular loci and total population: PhiPT-statistics by locus in age classes of $P$. abies.

\begin{tabular}{lcccccc}
\hline & Pt63718 & Pt26081 & Pt15169 & Pt30204 & Pt71936 & Total \\
\hline $\begin{array}{l}\text { Variance among age } \\
\text { groups }\end{array}$ & $0 \%$ & $1 \%$ & $18 \%$ & $2 \%$ & $6 \%$ & $2 \%$ \\
$\begin{array}{l}\text { Variance within age } \\
\text { groups }\end{array}$ & $100 \%$ & $99 \%$ & $82 \%$ & $98 \%$ & $94 \%$ & $98 \%$ \\
$\begin{array}{l}\text { Probabilitics for PhiPT- } \\
\text { statistics }\end{array}$ & 0.983 & 0.256 & 0.001 & 0.044 & 0.002 & 0.004 \\
\hline
\end{tabular}

Probability for PhiPT is based on 999 permutations across the full data set.

Table 3. - Nei's (1972) genetic distances between 5 age classes based on frequency of alleles at five chloroplast microsatellite loci.

\begin{tabular}{|c|c|c|c|c|c|c|}
\hline & & $\mathrm{E}$ & $\mathrm{S}$ & $\mathrm{Y}$ & $\mathrm{M}$ & $\mathrm{O}$ \\
\hline E & Open pollinated progeny-embryos & 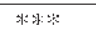 & & & & \\
\hline$S$ & $0-3$ years & 0,057 & 水品米 & & & \\
\hline $\mathrm{Y}$ & $4-10$ years & 0,010 & 0,070 & 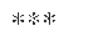 & & \\
\hline M & $11-100$ years & 0,040 & 0,022 & 0,039 & 米綜 & \\
\hline 0 & $>100$ years & 0,058 & 0,016 & 0,059 & 0.028 & $* * *$ \\
\hline
\end{tabular}

Hierarchical tests of the population structure in a set of samples from different age classes were performed taking into account the number of mutations between haplotypes under an infinite allele model and under a stepwise mutation model with the use of analysis of molecular variance (AMOVA, ExCOFFIER et al., 1992) as implemented in Arlequin (SCHNEIDER et al., 2000). The level of genetic differentiation between subpopulations was estimated using $\Phi$-statistics for haploid data (analogous to F-statistcs for diploid data) calculated via AMOVA option following MERIMANs (2006). The genetic distance between pairs of subpopulations was computed according to NEI (1972). Unweighted pair group method with arithmetic mean (UPGMA) analysis was used to generate a dendrogram of the relationships among the 5 age classes, supported by bootstrap analysis (TFPGA; MiLLER, 1997).

To further evaluate the genetic relationships between populations, we run Principal Coordinate Analysis (PCoA) based on the genetic distance between each age classes. We also clustered each class using bayesian approach as implemented in BAPS 6.0 software (CORANDER and TANG, 2007). The GenePop format of the data was used for the studied loci and ten independent runs were conducted for each $\mathrm{K}$ (1-5 for age classes and 1-30 for clustering of individual samples) to estimate the number of inferred groups. The number of iterations was set to 100 that were used to estimate the admixture coefficients for the individuals, number of reference individuals was set to 100 and the number of iterations that were used to estimate the admixture coefficients for the reference individuals was 10 . The number of populations was inferred as the combined maximum likelihood and highest posterior probability estimates over the runs.

\section{Results}

In five examined cpSSR loci, from 3 to 6 alleles were found (on average 5.2) in the whole examined sample of 290 individuals (Tab. 1). Range of the SSR lenght varied between $93-145$ base pairs (Table 1). The highest mean number of alleles per locus observed in the class of embryos was 4.4 , while the lowest value (3.4) was noted in the two oldest age classes of Norway spruce. Two private alleles were found in the class of embryos and seedlings and one in each of the two oldest groups. They were not observed only in the class Y (4-10 years). Generally, loci Pt63718, Pt15169 and Pt30204 were characterized by high frequency of one allele and lower frequencies of other alleles. In loci Pt26081 and Pt71936, the frequencies of two alleles were quite high and relatively similar, while those of other alleles were lower. In all the loci, considerable variance in the frequencies of alleles between individual age classes was observed. In the tree group 0-3 (S) and >100 (O), locus Pt15169 was monomorphic in allele 122. Results of analysis of molecular variance (AMOVA) indicate $2 \%$ variance between the age classes of the $P$. abies population (PhiPT-statistics, Table 2). Loci Pt15169 and Pt71936 proved to be the most differentiating, for which variance between the age classes was $18 \%$ and $6 \%$, respectively (probability of 0.001 and 0.002 ).

In the whole examined sample of 290 individuals, altogether 54 haplotypes were found: from 20 to 26 in separate age classes (Tab. 1). Five common haplotypes were 

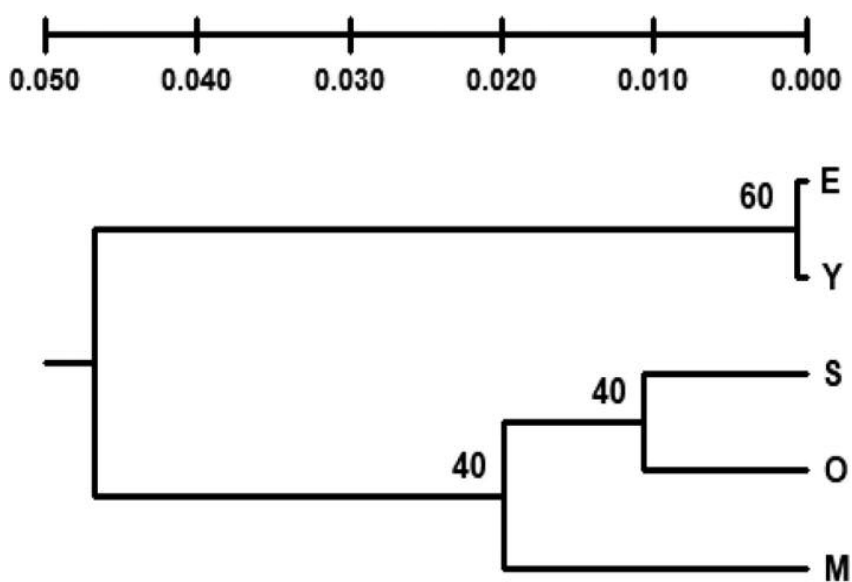

Figure 1. - Dendrogram constructed on the basis of genetic distances.

$\mathrm{O}=>100$ years, $\mathrm{M}=11-100$ years, $\mathrm{Y}=4-10$ years, $\mathrm{S}=0-3$ years, $\mathrm{E}=$ embryos.

observed with the mean frequency of $0.052-0.186$ in all the age classes. Private haplotypes were found in all the examined age classes including 8 in the class of embryos (E), 6 in the class $0-3(\mathrm{~S})$, and 5 in each of the other classes.

The mean genetic diversity $(\mathrm{H})$ of the chloroplast loci was the highest in the tree class of 4-10 years (Y) was 0.531 , and in the class of embryos (E) was 0.518 . In the other three classes the level was quite even and ranged from 0.354 to 0.393 (Table 1). The highest values of $\mathrm{H}$ in all the age classes were noted at the loci Pt26081 and Pt71936.

The greatest genetic distance according to NEI (1972) was found between the class of embryos and the class of the oldest trees -0.058 , as well as between the class of embryos and the class of seedlings -0.057 . The lowest distance was observed between the class of embryos and the class of trees of 4-10 years (0.01) (Table 3). PCoA analysis clearly identified two major groups including age class $\mathrm{E}+\mathrm{Y}$ vs. $\mathrm{S}+\mathrm{M}+\mathrm{O}$ and such two clusters were identified also in BAPS analysis $(\mathrm{K}=2, \log (\mathrm{ml})=-1269.22$, probability $=1)$. Genetic relationships between the age classes defined are shown at the dendrogram (Fig. 1).

\section{Discussion and Conclusions}

Chloroplast microsatellites are known in general to be highly variable markers (LEFORT et al., 1999) and due to their high level of variation in Norway spruce (VENDRAMIN et al., 2000) they should be considered as a useful molecular tools for studying gene flow and population differentiation. In our study we included five cpSSR markers that among others exhibited high levels of diversity in European Abies (VENDRAMIN and ZIEGENHAGEN, 1997; ZIEGENHAGEN et al., 1998; VENDRAMIN et al., 1999) and large polymorphism within four Swiss stone pine populations from the Carpathians (HöHN et al., 2005) Those loci proved high level of variability in Polish population of Norway spruce resulting in a high number of haplotypes within each age classes and providing adequate resolution for assessment of within population variation.

Our results demonstrate clear patterns of genetic differentiation in relation to demographic genetic substructuring within the population. From 5 to 8 private alleles were found in each of the age classes defined in our study except for the class represented by 4-10 years old trees. They account for $25 \%$ to $31 \%$ of all haplotypes in a given age class, respectively, which emphasizes variation of their genetic structure. Presence of populationspecific cpSSRs haplotypes was observed also by VENDRAMIN et al. (2000) in other parts of Norway spruce distribution in Europe. This characteristic seems to be a general peculiarity of conifer species (Provan et al., 1998) and within species differentiation among different sample cohorts within population was observed also in Populus and Fagus (LiTTle and DAle, 1999, TAKENAKA et al., 2002, Kitamura et al., 2008). The proportion of reported population-specific haplotypes ranged between $40 \%$ in Abies alba (VENDRAMIN et al., 1999) and $89 \%$ in halepensis-complex pines (BUCCI et al., 1998).

Previous study shows that chloroplast microsatellite variation in Norway spruce revealed a relatively low degree of differentiation among populations, typical for forest tree species with large distributions and efficient gene flow by pollen (VENDRAMIN et al., 2000). The proportion of the total genetic variation found between populations of widespread, wind-pollinated outcrossing conifer species is usually less than $10 \%$ (LEDIG, 1998). In the present research, a similar level of differentiation (2-18\%) was observed between separate age classes of one population. Locus Pt15169 turned out to be especially diverged in the group of seedlings and the two oldest tree groups (11-16\%). The class of embryos exhibited the greatest "genetic richness", expressed as the highest number of observed alleles and haplotypes, the highest mean number of alleles per locus, private alleles and haplotypes, and the highest value of haplotypic diversity. In the subsequent age classes, a decrease in genetic variation level was observed. Only the class of 4-10 years (Y) exhibited a very high level of haplotypic diversity, similar to that of the class of embryos. We suspect this is the consequence of the participation of many different trees as pollinators resulted from special environmental conditions (wind, flowering period, etc). In addition, each age class may be distinguished on the basis of several private alleles and haplotypes. Overall, the examined natural self-regenerated population of Picea abies showed narrowing of the gene pool in older generation of trees. Our analysis of variance of five cpSSR loci in five age classes of Picea abies of the Białowieża Primeval Forest supports the genetic patterns observed at isoenzyme loci (WoJNICKA-PÓ£TORAK et al., 2013). In contrast, results of the cpDNA study of 45 young and old individuals of Norway spruce from Austria (MAGHULY et al., 2006) revealed more private alleles in the old trees but similarly to our study the number of detected alleles was lower in old trees than in young trees.

Considerable genetic differentiation between separate age classes of the examined Norway spruce population may be a consequence of several factors including differ- 
ent participation of individuals from separate age classes in pollen generation and pollination or pollen inflow from outside the population. In fact the old trees are certainly not the only ancestors of the young age groups of the population and new alleles in young trees or embryos may suggest that reproductive gene pools may differ among reproductive episodes (CHUNG et al., 2003). The fact that private alleles occurs in old trees but are not present in young trees may be also explained by natural selection taking place in different stages of development of Picea abies population. A similar level of diversity between parental subpopulations and progeny of 6-10 years of Norway spruce $($ FST $=1-3 \%)$ was demonstrated in a study by MAGHULY et al. (2006) with the use of nuclear microsatellites. These markers exhibit a high degree of among-population differentiation and significant differences in allele frequency. Results of the isoenzyme study by LINHART et al. (1981) on Ponderosa pine population indicate significant differences in the genetic constitutions of trees occupying very different environments or located at different elevations. SCHNABEL and HAMRICK (1990) investigated the temporal genetic structure of Gleditsia triacanthos and found significant differences between age classes at nine allozyme loci out of the 27 examined loci.

Our study demonstrates that naturally renewing population of Norway spruce from the Białowieża Primeval Forest is genetically heterogeneous. The heterogeneity is likely related to age structure and reproductive events but also selection processes. The age structure of population has serious implications for sampling procedures of the studied material depending on the hypothesis tested and overall aims of the research study. As genetic structure is naturally dynamic, there is a need to study its fluctuations over time to better understand the mechanisms of successful survival and adaptation to environmental changes of forest tree populations (NAMKOONG, 1991; NiJENSOHN et al., 2005). Phenological observation in the investigated population and nucleotide polymorphisms analyses of other types of genetic markers including genomic regions potentially under selection are needed to enhance our knowledge on the factors that contribute to genetic and demographic structure of this unique natural forest stand.

\section{Acknowledgements}

The authors are grateful to dr. ŁUKASZ MYCZKo for his support in plant material collection in Białowieża Primeval Forest. This work was funded by the Ministry of Science and Higher Education in Poland, grant nr. 3P04F 00725.

\section{References}

BERG, E. E. and J. L. HAMrICK (1995): Fine-scale genetic structure of a turkey oak forest. Evolution 49: 110-120.

Bucci, G., M. Anzidei, A. Madaghiele, C. Sperisen and G. G. VENDRAMIN (1998): Detection of haplotypic variation and natural hybridisation in halepensis-complex pine species using chloroplast simple sequence repeat (SSR) markers. Mol Ecol 7: 1633-1643.
CorANDER, J. and J. TANG (2007): Bayesian analysis of population structure based on linked molecular information. Mathematical Biosciences 205 (1): 19-31.

Chen, X. Y. and Y. C. Song (1997): Temporal genetic structure of a Cyclobalanopsis glauca population in Huangshan. J East China Normal Univ (Nat Sci) (4): 79-84.

Chung, M. Y., B. K. Epperson and M. G. Chung (2003): Genetic structure of age classes in Camellia japonica (Theaceae). Evolution 57 (1): 62-73.

Echt, C. S., L. L. Deverno, M. Anzidei and G. G. VenDRAMIN (1998): Chloroplast microsatellites reveal population genetic diversity in red pine, Pinus resionsa, Ait. Mol Ecol 7: 307-316.

Ennos, R. A., W. T. Sinclair, X-S. Hu and A. Langdon (1999): Using organelle markers to elucidate the history, ecology and evolution of plant populations. In: Molecular Systematics and Evolution. Edited by P. M. BATEMAN and R. J. GoRNALL. Taylor \& Francis Ltd., London, pp. 1-19.

Excoffier, L., P. E. Smouse and J. M. Quatro (1992): Analysis of molecular variance inferred from metric distances among DNA haplotypes: application to human mitochondrial DNA restriction sites. Genetics 131: 479-491.

GebureK, T. (1997): Isozymes and DNA markers in gene conservation of forest trees. Biodivers Conserv 6: 1639-1654.

HAMrick, J. L., M. J. W. Godt and S. L. Sherman-Broyles (1992): Factor influencing levels of genetic diversity in woody plant species. New Forests 6: 95-124.

HöHn, M., P. Abran and G. G. Vendramin (2005): Genetic analysis of Swiss stone pine populations (Pinus cembra L. subsp. cembra) from Carpathians using chloroplast microsatellites. Acta Silv Lign Hung 1: 39-47.

Kitamura, K., K. Shimada, K. NaKashima and S. KaWAno (1997): Demographic genetics of the Japanese beech, Fagus crenata, Japan. II. Genetic substructuring among size-classes in local populations. Plant Species Biol 12: 137-155.

Kitamura, K., H. Takasu, S. Hagiwara, K. Homma, J. O'Neill, D. F. Whigham and S. KaWano (2008): Demographic genetics of American beech (Fagus grandifolia Ehrh.) IV. Development of genetic variability and gene flow during succession in a coastal plain forest in Maryland. Plant Species Biology 23 (1): 159-173.

KorczyK, A. F. (1994): Preservation of more than 200 year old Scots pine trees gene resources in the Białowieża Primeval Forest (in Polish and Beylarussian sides). Proc. of the IUFRO Symposium Lithuania 1994: Scots pine breeding and genetics: 101-103.

KonczYK, A. F. (2008): The stock-taking of old trees and threatened trees species in the Białowieża Primeval Forest. Forest Research Papers 69 (2): 117-126.

Korshikov, I. I. and E. A. MUDRIK (2006): Age dynamics of genetic variation in an isolated population of Chalk pine Pinus sylvestris var. Cretacea Kalenicz. Ex. Kom. From Donbass. Plant Genetics 42, No 5: 532-538.

LEDIG, F. T. (1998): Genetic variation in Pinus. In: RichARDSON, D. M. (ed) Ecology and biogeography of Pinus: 251-280. Cambridge University Press, Cambridge, UK

Lefort, F., C. Echt, R. Streiff and G. G. Vendramin (1999): Microsatellite sequences: a new generation of molecular markers for forest genetics. Forest Genetics 6: $15-20$. 
Linhart, Y. B., J. B. Mitton, K. B. Sturgeon and M. L. DAVIS (1981): Genetic variation in space and time in a population of Ponderosa pine. Heredity 46 (3): 407-426.

LitTLE, L. R. and M. R. T. DALE (1999): A method for analyzing spatio-temporal pattern in plant establishment, tested on a Populus balsamifera clone. J Ecol 87: 266-273.

Maghuly, F., W. Pinsker, W. Praznik and S. Fluch (2006): Genetic diversity in managed subpopulations of Norway spruce (Picea abies (L.) Karst.). Forest Ecology and Management 222: 266-271.

MatRAS, J. (2006): Ochrona leśnych zasobów genowych. In: Elementy genetyki i hodowli selekcyjnej drzew leśnych, SABOR, J. (eds) Centrum Informacyjne Lasów Państwowych, Warszawa, 573-577 (in Polish).

MERIMANs, P. G. (2006): Using the AMOVA framework to estimate a standardized genetic differentiation measure. Evolution 60: 2399-2402.

MilleR, M. P. (1997): TFPGA Version 1.3. A Windows program for the analysis of allozyme and molecular population genetic data. Dep. of Biol. Sci. Northern Arizona University.

Mosseler, A., I. Thompson and B. A. Pendrel (2003): Overview of old-growth forests in Canada from a science perspective. Environmental Review 11: 1-7.

NAMKOONG, G. (1991): Biodiversity-issues in genetics, forestry, and ethics. For Chron 68: 438-444.

NEI, M. (1972): Genetic distance between populations. Am Nat 106, 283-292.

NEI, M. (1978): Estimation of average heterozygosity and genetic distance from a small number of individuals. Genetics 89: $583-590$.

Nijensohn, S. E., P. G. Schaber, G. J. Hawley and D. H. DEHAYES (2005): Genetic subpopulation structuring and its implications in a mature eastern white pine stand. Can J For Res 35: 1041-1052.

OkoŁów, C. Z., M. KaraŚ and A. Воєвот (2009): Białowieski Park Narodowy-poznać, zrozumieć, zachować. Wydawnictwo BPN (in Polish).

Peakall, R. and P. E. Smouse (2012): GenAlEx 6.5: genetic analysis in Excel. Population genetic software for teaching and research-un update. Bioinformatics 28 (19): 2537-9.

Politov, D. V., M. M. Belokon and Yu.S. Belokon (2006): Dynamics of allozyme heterozygosity in Siberian Dwarf pine Pinus pumila (Pall.) Regel populations of the Russian Far East: comparison of embryos and maternal plants. Russian Journal of Genetics 42, 10: 1127-1136.

Provan, J., N. Soranzo, N. J. Wilson, J.W. McNicol, G. I. Forest, J. Cotrell and W. Powell (1998): Genepool variation in Caledonian and European Scots pine (Pinus sylvestris L.) revealed by chloroplast simplesequence repeats. Proc R Soc Lond Ser B-Biol Sci 265: 1697-1705.

Provan, J., W. Powell and P. M. Hollingsworth (2001): Chloroplast microsatellites: new tools for studies in plant ecology and evolution. Trends Ecol Evol 16: 142-147.

Roberds, J. H. and M. T. ConkLe (1984): Genetic structure in loblolly pine stands: allozyme variation in parents and progeny. For Sci 30: 319-329.
SCHNABEL, A. and J. L. HAMRICK (1990): Organization of genetic diversity within and among populations of Gleditsia tricanthos (Leguminosae). Am J Bot 77: 1060-1069.

Schneider, S., D. Roessli and L. Excoffier (2000): ARLEQUIN: a software for population genetics data analysis. University of Geneva. Available from: http://gb.unige.ch/arlequin/software

Schueler, S., S. Kapeller, H. Konrad, T. GebureK, M. Mengl, M. Bozzano, J. Koskela, F. Lefevre, J. Hubert, H. Kraigher, R. Longauer and D. C. Olrik (2013): Adaptive genetic diversity of trees for forest conservation in a future climate: a case study on Norway spruce in Austria. Biodivers Conserv 22 (5): 1151-1166.

Soltis, D. E., P. S. Soltis and B. G. Milligan (1992): Intraspecific chloroplast DNA variation: systematics and phylogenic implications. In: Molecular Systematics of Plants. Edited by P. S. Soltis, D. E. Soltis and J. J. DoYLE. Chapman and Hall, New York, pp. 117-150.

TAKenAKA, K., K. Kitamura, K. FURUbayashi and S. KAWANO (2002): Demographic genetics of Siebold's beech (Fagus crenata) populations on the Tanzawa Mountains, Kanagawa, central Honshu, Japan. I. Genetic substructuring among plots and size classes. J of Field Sci 1: 31-54.

Vendramin, G., L. Lelli, P. Rossi and M. Morgante (1996): A set of primers for the amplification of 20 chloroplast microsatellites in Pinaceae. Mol Ecol 5: 595-598.

Vendramin, G. and B. Ziegenhagen (1997): Characterization and inheritance of polymorphic plastid microsatellites in Abies. Genome 40: 857-864.

Vendramin, G. G., M. Anzidei, A. Madaghiele and G. BUCCI (1998): Distribution of genetic diversity in Pinus pinaster Ait. As revealed by chloroplast microsatellites. Theor Appl Genet 97: 456-463.

Vendramin, G. G., B. Degen, R. J. Petit, M. Anzidei, A. MAdAGHiele and B. Ziegenhagen (1999): High level of variation at Abies alba chloroplast microsatellite loci in Europe. Mol Ecol 8 (7): 1117-1126.

Vendramin, G., M. Anzidei, A. Madaghiele, C. Sperisen and G. BuCCI (2000): Chloroplast microsatellite analysis reveals the presence of population subdivision in Norway spruce (Picea abies K.). Genome 43: 68-78.

Williams, C. G. and J. L. HAMrICK (1996): Elite populations for conifer breeding and gene conservation. Can J of For Res 26 (3): 453-461.

Wojnicka-PóŁtorak, A., W. Prus-GŁowacki, K. Celiński and A. F. KorczyK (2013): Genetic aspects of age dynamics of a natural Picea abies (L.) Karst. population in the Białowieża Primeval Forest, Poland. New Forests DOI:10.1007/s11056-013-9367-7

Ziegenhagen, B., F. Scholz, A. Madaghiele and G. G. VENDRAMIN (1998): Chloroplast microsatellites as markers for paternity analysis in Abies alba. Can J of For Res 28 (2): 317-321. 